\title{
Forming the Rural Settlements in Early Republican Turkey
}

Özge Sezer ${ }^{1,1}$

${ }^{1}$ Berlin Technical University, Faculty VI, Department of Preservation of Historical Monuments.

\begin{abstract}
In the early Republican period of Turkey transformation of the rural areas occurred in a development programme that involved peasants. On the one hand, rural lifestyle was idealized in the national and cultural context. Also, the Turkish peasantry was considered as a significant labour resource for the agriculture-based economy. On the other hand, policies aimed to control the rural population in the new settlements, which were forms of internal colonization practiced especially during the second half of 1930 s. Starting from this point of view, the new rural settlements, built from 1934 to the end of 1930s, emerged significant examples to explain the Republican programme to modernize the village community under a united Turkish identity, even in completely diverse localities. This paper aims to re-open the discussion of Turkey's nation-building and modernization process from a perspective projected to the rural ideals, specifically to the Turkish village. It seeks to demonstrate how the policies of early Republican authority controlled rural Turkey in economic and socio-cultural terms, and altered the environment of the village community. It particularly focuses on the elaboration of ideas in architectural implementation during the early Republican period of Turkey. Consequently, this paper introduces the new rural settlements, emerging in the late 1930s in Turkey, pointing to their values as the historical monuments in Turkey's architectural culture.
\end{abstract}

\section{Introduction: planning the Turkish village in early republican Turkey}

The early Republican period of Turkey - from the post-First World War years to the late 1940 s - emerged from an observable dynamism in terms of socio-cultural and economic reforms, which resulted in a wave of implementation in the built environment fuelled by ideals of modernization and nation building. The Kemalist regime and the Republican People's Party grounded their endeavours on the rural populace and the village community that addressed the majority of the country, and this cadre sought to achieve progress in rural Turkey with a number of economic and socio-cultural programmes.

The first years of the republic witnessed several transformations in the social and cultural lives of the peasantry via the state's reforms. However, it was necessary to

\footnotetext{
${ }^{1}$ Corresponding author: ozgesez@gmail.com
} 
concentrate on the economy with the urgent adjustments in the country where out of the 13.6 million population 10.3 million were living in villages and small rural towns, and working in households and agrarian fields ${ }^{2}[1: 8 ; 2: 1]$. Moreover, the Lausanne Peace Treaty in 1923 stipulated the population exchange between Turkey and Greece, and during the first years of the republic almost 400 thousand people who were villagers and farmers, migrated into the country ${ }^{3}$ [3: 42]. Thus, the demographic, economic and social circumstances of Turkey in the early 1920s focused on the rural population as the greatest part of the country to be modernized and nationalized.

On $1^{\text {st }}$ March 1922, Mustafa Kemal Ataturk ${ }^{4}$ gave one of the most famous speeches in Turkey's political history: "The real warden and governor of Turkey is the villager who is the real producer. Then the villager deserves prosperity and wealth more than anyone else" [4: 239]. In order for "the real warden and governor of Turkey" to flourish, a series of state attempts started even before the proclamation of the republic on the $29^{\text {th }}$ October 1923. On $17^{\text {th }}$ February $-4^{\text {th }}$ March 1923 the First Economy Congress generated a programme to restore agriculturally grounded industry to sustain the village economy, which depended on agrarian labour for the landowners [5: 17-90; 6: 25, 5790]. Then, in 1924, the Village Law was enacted, determining the village to be a legal entity $^{5}$ [9: 7-27]; in 1926, the government started the implementation of the first Settlement Law considering the organization of new settlements and economic orientations of rural communities [8: 76-80]; and in 1929 Agricultural Credit Cooperatives were legalized to support farmers and villagers who held lands in the cultivated areas, and who worked in agricultural labour ${ }^{6}$.

As well as economic adjustments for the development of village community, the Republican regime started a cultural programme in order to fulfil its social engineering aspirations for rural Turkey. From $1930^{7}$ to 1945 , the Republican People's Party, with which the Turkish state was then completely identified, operated this agenda $[9,10]$. In 1932, the Republican People's Party founded the People's Houses to transfer Kemalist reforms to the countryside via an education programme for adults [11: 69]. The

\footnotetext{
${ }^{2}$ Around 1923 the major populace of Turkey consisted of landowners, small agriculture holders and non-landowner villagers, especially after the Armenians and Greeks who were traditionally holding the trade and capital network, were forced to leave during the First World War and the Greco-Turkish War.

${ }^{3}$ Turkey and Greece entered into agreement of Convention Concerning the Exchange of Greek and Turkish Population on $30^{\text {th }}$ January 1923. The agreement contained the population exchange also proclaimed in Treaty of Lausanne on $24^{\text {th }}$ July 1923 . See the 2 . Article in the Part VI of the treaty: Lausanne Peace Treaty VI. Convention Concerning the Exchange of Greek and Turkish Populations Signed at Lausanne (1923). January 30. Retrieved from: www.mfa.gov.tr/lausannepeace-treaty-vi_-convention-concerning-the-exchange-of-greek-and-turkish-populations-signed-atlausanne_.en.mfa [available on 6 March 2019].

${ }^{4}$ 1881-1938, the first Republican President of Turkey.

5 The Village Law (1924). $18^{\text {th }}$ March. Retrieved from: www.mevzuat.gov.tr/MevzuatMetin/1.3.442.pdf [available on 6 March 2019].

${ }^{6}$ On $21{ }^{\text {st }}$ October 1935, the law for Agricultural Credit Cooperatives reviewed within the new law numbered 2836 including a larger state control in the credits and partnerships. See: The Law for Agricultural Credit Cooperatives (1929). $28^{\text {th }}$ May. Retrieved from: www.resmigazete.gov.tr/arsiv/1208.pdf [available on 6 March 2019]; The Law for Agricultural Credit Cooperatives (1935). $21^{\text {st }}$ October. Retrieved from: https://www.tbmm.gov.tr/tutanaklar/KANUNLAR_KARARLAR/kanuntbmmc015/kanuntbmmc015 /kanuntbmmc01502836.pdf [available on 6 March 2019].

7 In 1930, the multiparty system was shortly introduced in Turkey. Liberal Republican Party Serbest Cumhuriyet Fırkası was established by Fethi Okyar in August 1930. However, it was dissolved after four months due to the strong opposition against Kemalist reforms.
} 
organization developed into a local mouthpiece of the state and a crucial instrument for governing and controlling the rural population.

In following the programme, the particular branch for the villages started peasant education in the associations. This branch essentially concentrated on the improvement of rural culture by promoting artistic and craftsmanship activities into the village with the participants from village and city working together. The branches worked on the obstacles in the village life in order to change the rural builtenvironment in a modern sense. The Village Affairs branches of People's Houses organized several excursions that examined how to create bonds between urban and rural people who were not only geographically distant from each other, but also culturally and socially disconnected [12: 127].

The programme of People's Houses evolved in different directions in the following years including the establishment of Village Institutes - a specific educational institution in the countryside. The idea was created in mid-1930s intending to train educators for instructing villagers about their daily needs. From their legalization in 1940 to the close in 1954, these institutions followed a pathway between proposed socio-cultural transformations and economic progress in rural Turkey that involved many actors, not only politicians and the urban intelligentsia, but also villagers and, indeed, feudal landowners [13]. This was possibly a promising grass-roots rise from the bottom of the society, instead of a top-down progress, which had been implemented within the Kemalist ideals by the republican cadre since the early 1920 s.

\section{Building the republican villages: practices and debates}

\section{Practices during the first years}

It is a matter of consequence that architectonic implementations, which were generated in accordance with the economic and socio-cultural planning of the Turkish Village, echoed the republican venture, and became concrete examples of the ideology in rural Turkey. The construction of new settlements emerged as an observable practice for the economic aspects in the first years of the republic, and for the social and national aspects after 1930 until the late 1940s in the country planning.

During the first years of the Republican regime, the construction of rural settlements was generated within the frame of re-housing the existing population and settling the exchanged population coming from the former Ottoman territories after the First World War and the Greco-Turkish War. All the correspondence and ministry council decisions during the 1920s demonstrated the lack of economic and organizational structures and presented a consensus view about the urgency of housing the incoming people, sanitary improvements in existing villages and the construction of dwellings in rural areas with the modern facilities.

The first years' operations were carried out by the state, implementing the 1924 Village Law and the 1926 Settlement Law. The Ministry of Population Exchange and Housing organized the construction of new settlements in 10 regions where the larger cities and towns had sufficient infrastructure, convenient areas for village construction and also abandoned properties [14: 52-53]. In relatively developed provinces like Samsun, Bursa, İzmir, İzmit, Manisa, Ankara and Adana, new villages started to be constructed consisting of dwellings, schools and mosques. In 1933, there were 69 new 
settlements [14: 66; 15: 19; 16: 203; 17: 28-29; 18: 115-116] built and under construction also for the immigrants from Bulgaria and Romania ${ }^{8}[19]$.

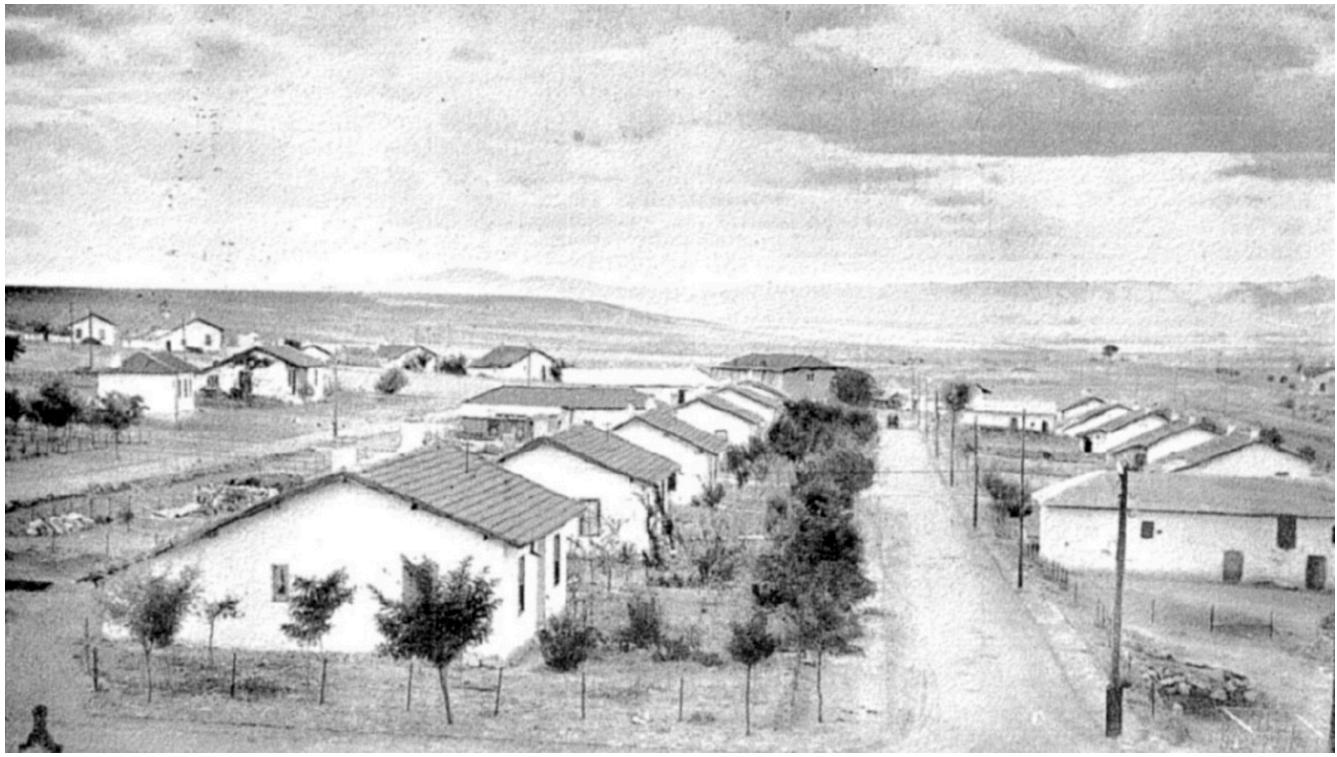

Figure 1: Etimesgut Village built in Ankara from 1925 to early 1930s. (Source: [20])

Until the early 1930s the village planning was carried out by the Republican regime, so as to overcome the concrete obstacles in the country, such as restoring the building stock and the infrastructure in cities and towns, housing the population and providing for the economic sufficiency in the country. Thus, the first implementations had the tone of utilitarian endeavour more than an idealisation of the rural Turkey.

\section{Debates in Forming the New Rural Settlements}

Turkish architects, especially after 1930, looked at the construction of new rural settlements as a crucial debate. According to some scholars, the spatial organization of these settlements were incompatible with fulfilling the social needs of the rural community. Thus, they introduced a series of "ideal villages" conforming the modern and national considerations. Most of the time, the proposals consisted of a modernized building programme with an emphasis on the cultural and social agenda of Kemalism, in a rational geometrical organization of village houses, which were presented with local materials and construction techniques [21: 116; 22: 38; 23].

These approaches were doubtless different from existing villages in Anatolia. Scenarios, under the theme of "ideal villages" were adaptation projects of "ideal city" models in Europe which emerged from the end the $19^{\text {th }}$ century [24: 153]. One of the

${ }^{8}$ On $18^{\text {th }}$ October 1925 , the Treaty of Amity between Turkey and Bulgaria was concluded. From 1930 to 1939 more than 80,000 Turco-Bulgarians immigrated into the country. On the $17^{\text {th }}$ October 1933, the Treaty of Amity between Turkey and Romania was concluded. The treaty also paved the ways for the immigration of the Turco-Romanian populace into the country. See: Report on Treaty of Amity Between Romania and Turkey (1992). $17^{\text {th }}$ October 1933. Retrieved from: https://www.tbmm.gov.tr/tutanaklar/TUTANAK/TBMM/d19/c032/tbmm19032080ss0157.pdf [available on 6 March 2019]. 
significant examples, introduced by Kazim Dirik $^{9}$ in 1937, was an adaptation of Ebenezer Howard's Garden City diagram. The "Ideal Republican Village" ${ }^{10}$ was demonstrated in a radial scheme organized from the centre to the outer segments, hence from public facilities to the housing areas.

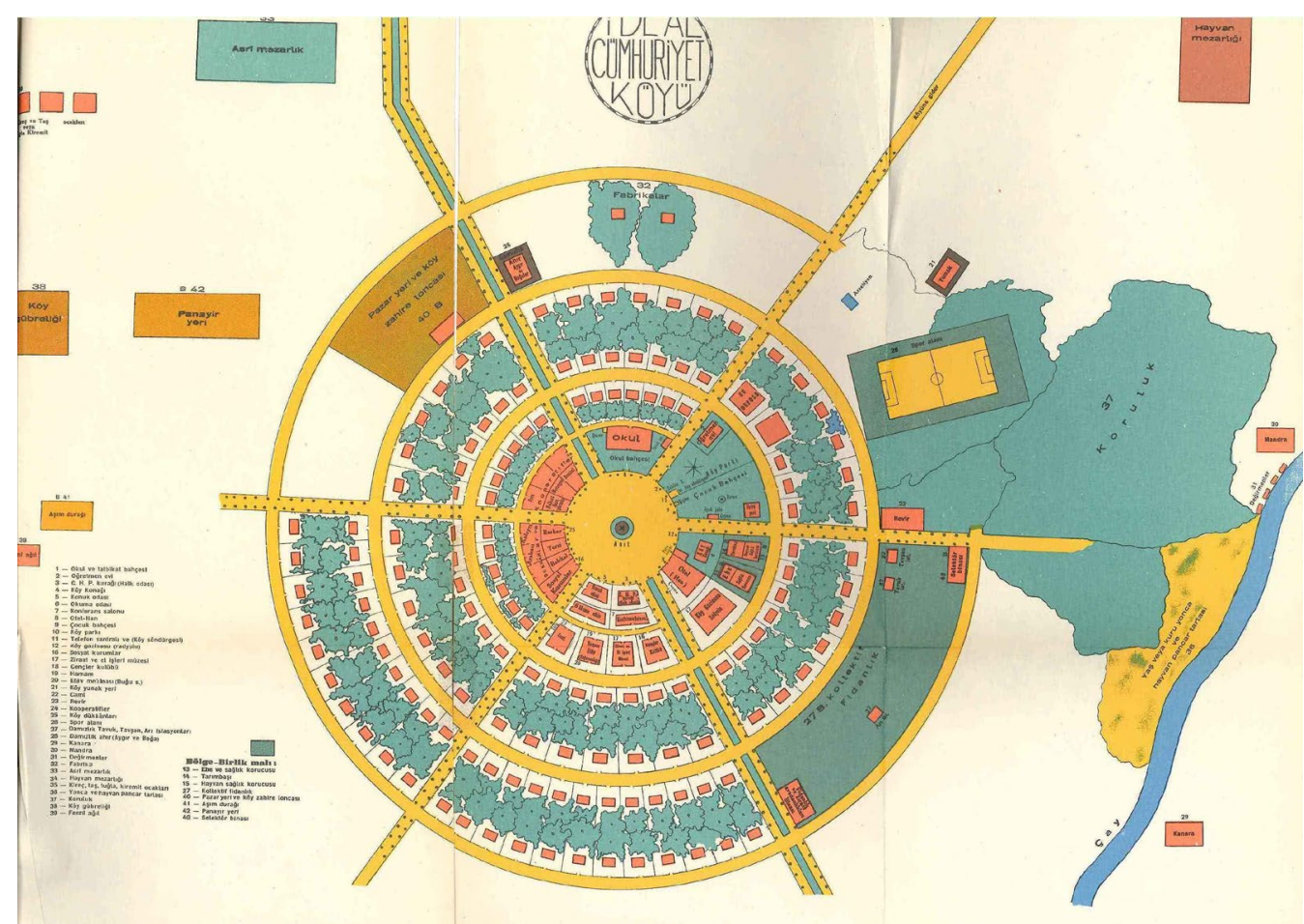

Figure 2: The "Ideal Republican Village" as presented by Kazim Dirik in 1937. (Source: ${ }^{10}$ )

Additionally, the agrarian colonies, which had been built in Germany since the $19^{\text {th }}$ century, were enthusiastically introduced as a model for new rural settlements in Turkey. According to the architect Zeki Sayar "11 "nation building with agricultural colonies show[ed] an aim for a new life style in the countryside" [25: 232]. This structure would also serve for economic fulfilment and progress in the social environment of the Turkish village. "Internal Colonization" with agrarian colonies would accomplish a civilized lifestyle equipped with modern aspects in architecture such as standardization, variation in typology and a utilitarian view in material-use. Zeki Sayar advocated a systematic design approach in order to improve not only physical conditions, but also socio-cultural circumstances in rural Turkey [25: 47].

\section{Practices of New Rural Settlements for Modernization and Nation Building}

During the 1930s debates repeated the tone of the state's endeavour in modernization and nationalization of rural Turkey and they were gradually echoed in the practices, new

9 1881-1941, Governor of Izmir Province from 1926 to 1935 and Inspector General of Trace Region from 1935 to 1941.

${ }_{10}$ DíRiK, K. 1937. “ideal Cumhuriyet Köyü”, Document, Turkey's State Archive (TCBCA), 30.1.0.0/111.705.8.

${ }^{11}$ 1905-2000, architect and publisher of Turkey's first architecture and urbanism journal Arkikekt. 
regulations and legislation while the Republican People's Party consolidated its political power in the village community, which was still the major part of the country. In other words, after 1930s the Kemalist regime added a rigid nation-building agenda to the organization of rural settlements except from pragmatic solutions for the housing problem and economic adjustments in the rural areas.
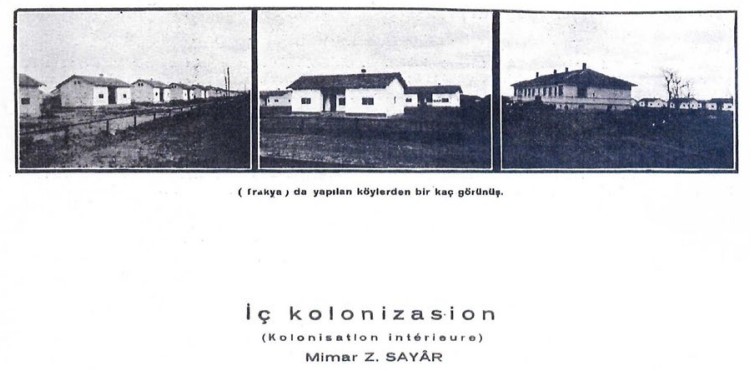
Mimar Z. SAYÃR

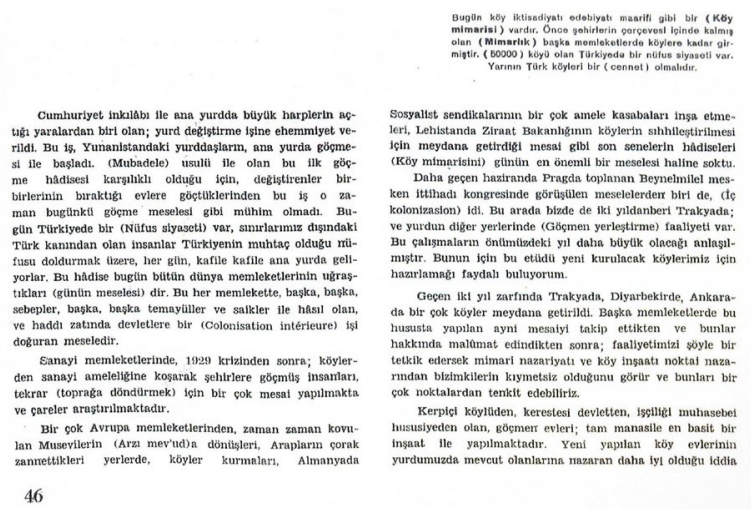

Figure 3: A page from Zeki Sayar's article on internal colonization in Turkey's first architecture magazine Arkitekt in 1936. (Source: [25: 46])

After the political reinforcement of the regime in 1930 the village appeared more strongly as target of the Republican People's Party's tactics for building the nation, projecting the idea of "turkification" on local ethnic groups and immigrants. As part of the new Settlement Law of June $14^{\text {th }} 1934$ building the new villages assumed new dimensions: rural settlements were not only planned in order to house immigrants and the local populace who needed the improvement in living conditions but they were also instrumentalised in order to govern the masses in rural Anatolia within the demographic programme of the state.

According to the 1934 Settlement law and its regulations as announced until 1936, Turkish immigrants should be settled with other family members within the same or the nearest settlements and be engaged in agricultural activities. Conversely, non-Turkish groups had to settle where the government decided. They would be housed in villages where they could only speak Turkish. They would not be neighbours with each other and there had to be at least 10 Turkish-speaking dwellings between their houses; only in this way would they be acquainted with Turkish culture [26: 248-249]. 
Nevertheless, the regulations included clarifications on aspects such as sanitation, transport, agrarian facilities, organization of planning and construction works in new rural settlements [26: 259-276]. It was introduced that a settlement area should be convenient for 100 houses, well connected to the transport network (railway, highway or harbour) and suitable for agriculture. Each house in the settlement should be located on a parcel of $500 \mathrm{~m}^{2}-1.000 \mathrm{~m}^{2}$. Each family should have at least $3.000 \mathrm{~m}^{2}$ area of land around the village for agriculture. The construction area would be determined by the local governorate, while site plan and details should be designed by local experts, including a doctor, an engineer, a cadastral technician and a housing technician. In addition, all plans and drawings would be approved by the local governorate [26: 264-268].

Implementation of the 1934 Settlement Law started in several provinces in the country, including the construction of complete new settlements and dwelling areas in existing villages. Up to the early 1940s one settlement as created in each of Ankara, Antalya, Corum, Istanbul and Yozgat districts; in Diyarbakir two; in Izmir ${ }^{12}$ three and in Elazig eleven new settlements were under construction, and in eastern Thrace more than 13 thousand dwellings were built to house the incomers [18: 154-155, 185; 28: 58; 29: $2 ; 30 ; 31 ; 32: 9]$.

The new rural settlements built in Izmir (in the western coast of Turkey) and Elazig (in the south-eastern Turkey) were typical examples of the regulations of the new settlement law. The villages Yenikoy, Taskesik and Havuzbasi in Izmir were located on cultivated land where the British companies had constructed the infrastructure, connecting the areas to the harbour in the late $19^{\text {th }}$ century and remained before the First World War. According to the official documents, the governorate of Izmir built settlements for immigrants consisting of 16 houses in Havuzbasi, 18 in Taskesik and 140 in Yenikoy. It was pronounced that the local authority of Izmir implemented a housing specification which contained two rooms under a timber roof, a small barn and orchard in the garden [27: 133-137]. There were several other implementations of the 1934 law in Izmir dwelling groups in the existing towns and villages were built. However, Havuzbasi, Taskesik and Yenikoy emerged as crucial examples for demonstrating how regulations were applied in complete settlements. In the annual catalogue of 1938, it was also announced that the government supplied the agricultural land, animals and farming equipment to the settlers in the region.

The new villages in Elazig reflected the practices of different housing typologies in the villages which were abandoned following the Armenian deportation during the First World War, and were taken over by the state to house both immigrants and locals together ${ }^{13}$. According to the official documents, in 1935 in Bizmisen 80 dwellings and in Hulvenk 80 dwellings were constructed as one-storey adobe-buildings consisting of two rooms; while in Habusu 26 dwellings, in Etminik 89 dwellings, in Vertetil 17 dwellings and in Percenc 26 dwellings consisting of two storeys with three rooms were constructed out of masonry. The state supported the agricultural activities supplying the land and farming equipment to the settlers in accordance with the development plan for the region [34].

\footnotetext{
${ }^{12}$ In Izmir, the government organized the construction of rural houses for the immigrants in the existing villages and rural districts. In 1938, 521 houses were completed in the convenient rural areas in Izmir. See [27: 136-137].

${ }^{13}$ Elazig province emerged as the centre in the eastern Turkey and a unique place for the internal colonization according to development plan of Republican regime especially during the 1930s considering the agricultural and industrial potentials of its hinterland, and also the potentials of turkification. For a further reading on early Republican architectural culture in Elazig, see [33].
} 

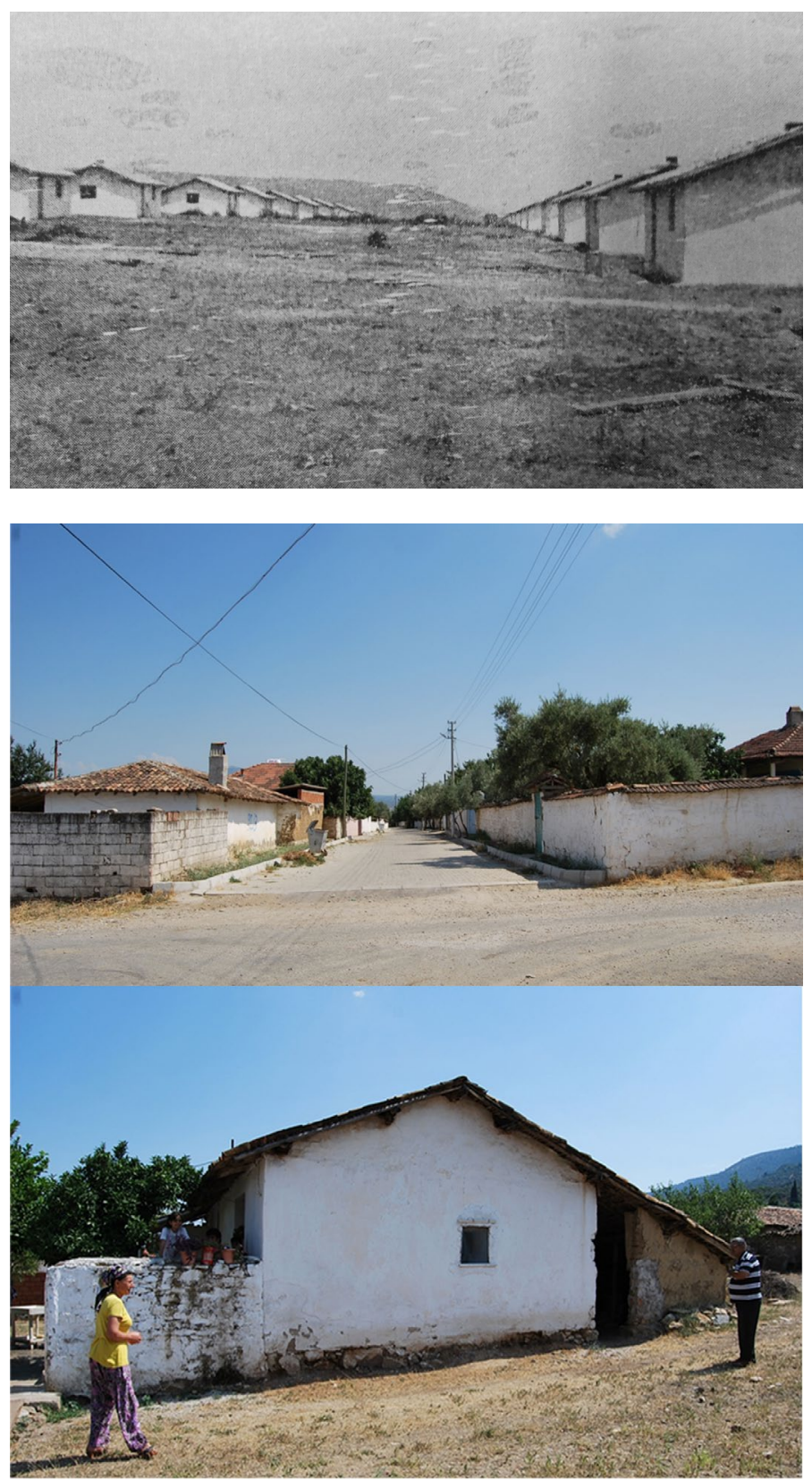

Figure 4: a) Yenikoy Village in Izmir, 1938 (Source: [27: 137]) and b) today (photograph by author) 

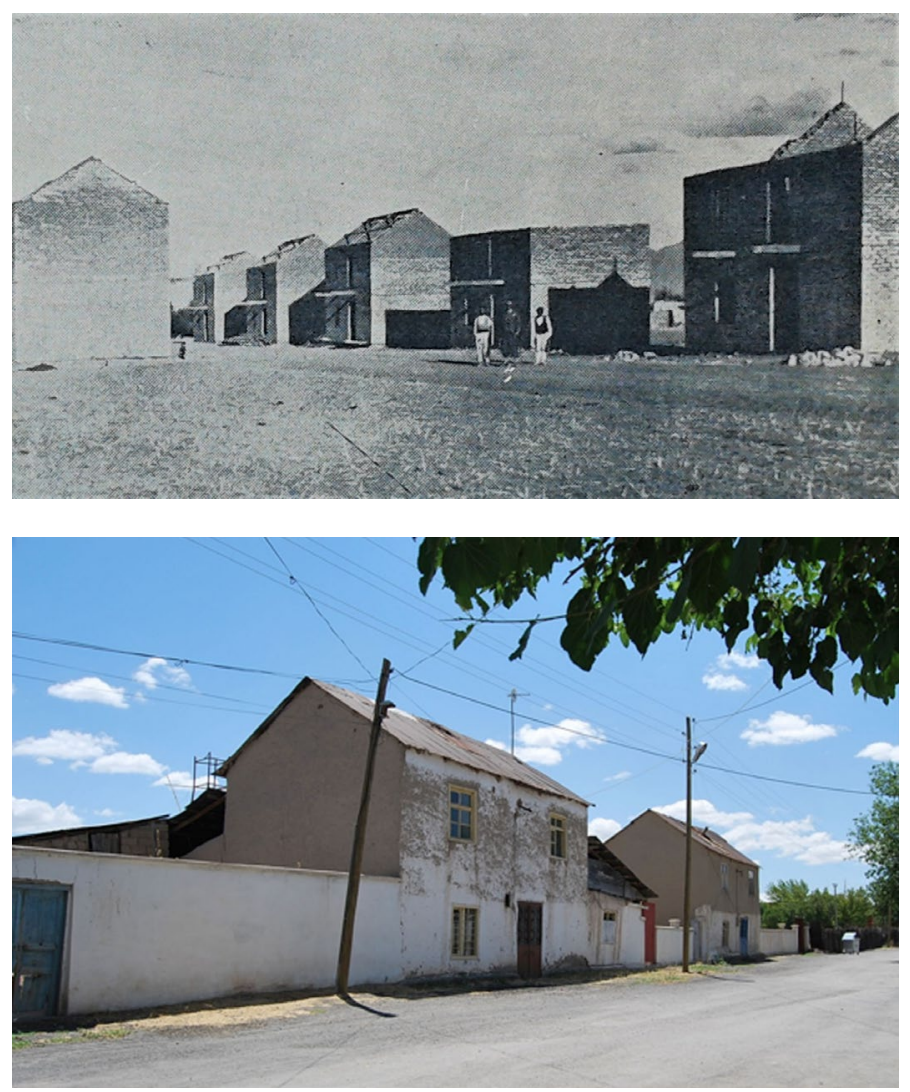

Figure 5: a) Vertetil Village in Elazig in 1935 (Source: [34] and b) a view from today (photograph by author).

\section{Conclusions}

Idealization of the Land emerged as a vigorous concept after the "rural depopulation, anxieties about urbanization and the impact of the agricultural depression" [35: 147] in the Western World [36]. In many cases, regeneration of the countryside became a pivotal programme and, controversially, modernization in agricultural life generated itself in social, economic and cultural aspects. In other words, it was believed that education and training for cultivating the country's land would lead to significant development in rural output which would help solving other problems such as rural depopulation, poverty and divergence for the cultural and national agenda of the state. However, the cultural and national agenda of the state was nourished by the examination of rural tradition and, at the same time, its notions that were reflected in the nation-building propaganda. The dilemma firstly led "rural idealism" to somewhere it had been justified by utilitarian goals, such as modernization of the land; secondly and repeatedly it provoked a romanticist approach to the countryside which had been prominent movement since the $19^{\text {th }}$ century.

Similarly, during the early Republican period, Anatolia was presented as an idealized land where the authorities and intelligentsia grounded the cultural roots of the new Turkish state. Meanwhile, they led the nationalization and modernization programme targeted directly to the village communities that formed the major part of the country. Ideals and their implementations carried the great tone of Western ideas in order to 
transform Turkey's society, which, however, had a very heterogeneous structure, and low self-awareness in socio-cultural and economic terms. Starting especially from 1930s, the Republican regime sought to transform the rural population through endeavours in cultural, social and economic developments, and construction of the new Turkish nation.

Consequently, the new rural settlements assisted in governing the rural people under the frame of the village community of which conceptions were determined in regulations by the state, and in design schemes by state planners. During the 1930s and early 1940s the new Republican villages clearly demonstrated the instrumentalisation of architecture in Turkish country planning that served to create a particularly organized and controlled built environment for the villagers. They also mirrored the operations that the Republican regime switched between: whether rural Turkey happened to be a romantic picture to admire and examine, or an empty canvas to be painted upon by the authority itself.

*This paper is based on author's doctoral research.

\section{Short resume}

Özge Sezer was born in Izmir, Turkey. She received her Bachelor Degree in Architecture from Izmir Institute of Technology, Faculty of Architecture in 2007, and Master of Architecture Degree from Istanbul Technical University, Faculty of Architecture, Department of History of Architecture in 2010. She worked in several conservation projects in Turkey. In 2018, she completed her doctoral studies with the degree of Magna Cum Laude in Berlin Technical University, Department of Preservation of Historical Monuments under the supervisions of Prof. Dr. Gabriele DollfBonekämper (TU Berlin) and Prof. Dr. Zeynep Kuban Tokgöz (TU Istanbul).

\section{References}

1. T.C. BAŞBAKANLIK DEVLET ISTATISTIK ENSTITÜSÜ (ed), 1994. İstatistik Göstergeler - Statistical Indicators, 1923-1992, Ankara, T.C. Başbakanlık Devlet İstatistik Enstitüsü.

2. KÖYMEN, O. 1999. "Cumhuriyet Döneminde Tarımsal Yapı ve Tarım Politikaları", in O. Baydar, O. Köymen (eds), 75 Yılda Köylerden Şehirlere, Istanbul, Türkiye Ekonomik ve Toplumsal Tarih Vakfı: 1-30.

3. KIRCA, İ. T. 2014. Insan ve Mekân Yüzüyle Mübadele: 1923'ten Bugüne Zorunlu Göç, İstanbul, İnkılâp.

4. ANKARA ÜNIVERSITESI TÜRK INKILAP TARIHI ENSTITÜSÜ (ed.), 2006. Atatürk'ün Söylev ve Demeçleri I-III, Ankara, Atatürk Araştırma Merkezi.

5. AFETINAN, A. (ed.) 1982. Izmir Iktisat Kongresi, 17 Şubat - 4 Mart 1923, Ankara, Türk Tarih Kurumu Basımevi.

6. KEYDER, Ç. 1981. The Definition of a Peripheral Economy: Turkey, 1923-1929, Cambridge - New York - Paris, Cambridge University Press - Editions de la Maison des sciences de l'homme.

7. SOYLU, G. 1940. Köy Nedir ve Nasıl Idare Edilir, Istanbul, Marifet Basımevi.

8. Iskan Tarihçesi (1932). Istanbul, Hamit Matbaası.

9. AĞAOĞLU, A. 1994. Serbest Fırka Hatıraları, Istanbul, İletişim. 
10. OKYAR, O.; SEYITDANLIOĞLU, M. 1999. Fethi Okyar'ın Anıları: Atatürk-Okyar ve Çok Partili Türkiye, İstanbul, Türkiye İş Bankası Kültür Yayınları.

11. KARAÖMERLiOĞLU, A. 1998. "The People's Houses and the Cult of the Peasant in Turkey", Middle Eastern Studies, vol. 34, n 4: 67-91.

DOI: https://doi.org/10.1080/00263209808701244

12. ÇEÇEN, A. 2000. Atatürk'ün Kültür Kurumu Halkevleri, İstanbul, Cumhuriyet.

13. KARAÖMERLiOĞLU, A. 1998. "The Village Institutes Experience in Turkey", British Journal of Middle Eastern Studies, vol. 25, $\mathrm{n}^{\circ} 1$ : 47-73.

DOI: https://doi.org/10.1080/13530199808705654

14. ARI, K. 1995. Büyük Mübadele: Türkiye'ye Zorunlu Göç, 1923-1925, Istanbul, Tarih Vakfı Yurt Yayınları.

15. IPEK, N. 1996. "Göçmen Köylerine Dair”, Tarih ve Toplum, vol. 150.

16. KOZANOĞLU, A. Z. 1935. "Köy Evleri Proje ve Yapıları İçin Toplu Rapor”, Arkitekt, vol. 55-56, $n^{\circ} 7-8$.

17. CENGIZKAN, A. 2004. Mübadele Konut ve Yerleşimleri, Ankara, Orta Doğu Teknik Üniversitesi, Mimarlık Fakültesi.

18. ERES, Z. 2008. Türkiye'de Planlı Kırsal Yerleşmelerin Tarihsel Gelişimi ve Erken Cumhuriyet Dönemi Planlı Kırsal Mimarisinin Korunması Sorunu, Unpublished Doctoral Thesis, Istanbul Technical University.

19. KAŞTAN, Y. 2008. "Atatürk Dönemi Türkiye-Bulgaristan İlişkileri”, Atatürk Araştırma Merkezi Dergisi, vol. 24, $\mathrm{n}^{\circ}$ 72. Retrieved from: http://www.atam.gov.tr/dergi/sayi-72/ataturk-donemi-turkiye-bulgaristan-iliskileri [available on 6 March 2019].

20. Yabancı Gözüyle Cumhuriyet Türkiyesi (1938). Ankara, Dahiliye Vekaleti, Matbuat Umum Müdürlüğü.

21. BOZDOĞAN, S. 2001. Modernism and Nation Building: Turkish Architectural Culture in the Early Republic, Seattle, University of Washington Press.

22. KOZANOĞLU, A. Z. 1933. "Köy Mimarisi”, Ülkü, vol. 7.

23. SEZER, Ö. 2017. "Turkey's Modernization and Nation Building Processes" in D. Hambly (ed.), Mapping Nations Locating Citizens: Interdisciplinary Discussions on Nationalism and Identity, Toronto, Humber Press: 56-74. Retrieved from: https://www.academia.edu/34295779/Mapping_Nations_Locating_Citizens_Interdis ciplinary_Discussions_on_Nationalism_and_Identity [available on 6 March 2019].

24. NALBANTOĞLU BAYDAR, G. 1997. "Silent Interruptions: Urban Encounters with Rural Turkey", in S. Bozdoğan, R. Kasaba (eds.), Rethinking Modernity and National Identity in Turkey, Seattle - London, Washington University Press: 192210.

25. SAYAR, Z. 1936. "İç Kolonizasyon: Başka Memleketlerde”, Arkitekt, vol. 68, n 8.

26. T.C. SIHHAT VE IÇTIMAI MUAVENAT VEKALETI ISKAN UMUM MÜDÜRLÜĞÜ (ed.), 1936. İskan Mevzuatı, Ankara, Köyöğretmeni Basımevi.

27. Cumhuriyetin 15inci Yılında Izmir (1938). Izmir, C.H.P. Basimevi.

28. ERES, Z. 2014. "Erken Cumhuriyet Döneminde Çağdaş Kırsal Kimliğin Örneklenmesi: Planlı Göçmen Köyleri”, Mimarlık, vol. 365, n 1.

29. "Yeni Yaptırılacak Göçmen Evleri” (1937). Anadolu, $21^{\text {st }}$ July 1937, Izmir.

30. "Şarımızda Olup Bitenler: İskanda" (1935). Altan, June 1935, 10-11. 
31. "Şarımızda Olup Bitenler: İskan İşleri" (1935). Altan, July 1935, 10.

32. "Şarımızda Olup Bitenler: Tapuda" (1935). Altan, December 1935, 9, 12.

33. KEZER, Z. 2014. "Spatializing Difference: The Making of an Internal Border in Early Republican Elazığ, Turkey", Journal of the Society of Architectural Historians, vol. $73, n^{\circ} 4:$ 507-527.

DOI: https://doi.org/10.1525/jsah.2014.73.4.507

34. Elaziz Illi Cumhurluk Devirinde II ve Illçelerde Kültürel Bayındırlık Iş̧leri (1935). Istanbul, Resimli Ay Basımevi.

35. BURCHARDT, J. 2010. "Editorial: Rurality, Modernity and National Identity between Wars", Rural History, vol. 21, n 2: 143-150.

DOI: https://doi.org/10.1017/s0956793310000087

36. BURCHARDT, J. 2007. "Agricultural History, Rural History, or Countryside History?", The Historical Journal, vol. 50, n 2, p. 465-481.

DOI: https://doi.org/10.1017/S0018246X07006152 